\title{
Hardening of the national flower of Colombia, the threatened Cattleya trianae (Orchidaceae), from in vitro culture with previous invigoration phase
}

\author{
Marcela Franco ${ }^{1,2}$, Giovany Guevara ${ }^{1}$, Neftali Mesa ${ }^{2} \&$ Gloria Urueña ${ }^{2}$ \\ 1 Instituto de Zoología, Facultad de Ciencias, Universidad Austral de Chile, Campus Isla Teja, Valdivia, Chile; \\ lidafranco@uach.cl \\ 2 Laboratorio de Cultivo de Tejidos, Facultad de Ciencias, Universidad del Tolima, Altos de Santa Elena, A.A. 546, \\ Ibagué, Tolima, Colombia.
}

\author{
Received 30-XI-2004. Corrected 12-I-2007. Accepted 28-II-2007.
}

\begin{abstract}
Cattleya trianae is an endemic species from the tropical rainforest in the Colombian Andes. Its survival is currently threatened due to habitat loss and commercial overexploitation. This study evaluates ten substrates, some organic (pine bark, coconut fiber and wood shavings), some inert icopor (polystyrene foam), vegetable coal and their combinations, and the effects these have on morphometric and phenotypic traits in the hardening phase of 250 plants of $C$. trianae cultivated in vitro. Recorded data include percent survival, length of longest leaf, biomass (wet weight) and number of roots and leaves at the beginning and at the end of the experiment. After the hardening phase, the plants were taken to a greenhouse and later to the natural environment. Coconut fiber alone or mixed in equal parts with pine bark and coal was the most efficient substrate when percent survival ( $80 \pm \mathrm{SE}=0.3742$ ), biomass, and leaf length were evaluated. Hardened plants displayed qualitative characteristics such as vigor, hardness and waxy texture, strength of green coloration in the leaves, and velamen formation. Under greenhouse conditions, plants grew better with filtered light, relative humidity bordering on $80 \%$, permanent aeration, misting with water, and an average temperature of $25 \pm 2{ }^{\circ} \mathrm{C}$. Invigorated plants were firmly anchored on their host trees. Rev. Biol. Trop. 55 (2): 681-691. Epub 2007 June, 29.
\end{abstract}

Key words: acclimation, hardening, substrates, ornamental, orchids, conservation, Cattleya trianae.

Systematic degradation of natural ecosystems, deforestation, and anthropogenic impacts on tropical rainforests (Ortiz 1995), associated to the difficulty of natural propagation, and the boom in flower cultivation and commerce, contribute to the strong degradation and reduction of wild orchid populations. In Colombia, as in other tropical countries of the Americas, orchids embody one of the greatest expressions of floristic richness; not only for their beauty and color, but also for their capacity to adapt to almost every climate and natural condition (Ospina 1974, Krapiec et al. 2003).

Cattleya trianae (Linden and Reichb $1860)$ is an endemic species found in the Colombian Andes at altitudes ranging from 600 to $1940 \mathrm{~m}$, and its distribution is restricted to the Alto Magdalena watershed, in the states of Huila, Tolima and Cundinamarca (Constantino and Calderón 2002). It was declared the national flower of Colombia in 1936 (Ospina 1974, Díaz 1987) and is classified as a threatened species in Appendix I on the CITES convention (2003).

In Colombia, this orchid is a valuable commodity, making its conservation more problematic since nurseries utilize native forests as extraction sites of source plant material (Ospina and Dressler 1979). C. trianae has been cultivated using primarily the rhizome from the tree fern Cyathea sp. as a propagation medium. The fern is found mainly in the Andean mountain 
ranges at 0-4 $200 \mathrm{~m}$ in elevation, and since 1977 has been included in Appendix II of the CITES convention as a threatened species (Murillo and Murillo 2003). Therefore, this study aims to reduce the impact of indiscriminate extraction on the two species $(C$. trianae and Cyathea sp.) in native forests to supply nurseries and businesses. We promote in vitro culture and use of alternative substrates during the hardening stage.

During the in vitro stage, plants are kept in a controlled environment, characterized by high humidity, low light intensity, supplementary sugar supply, and growth regulators (Murashige 1974, Viegas et al. 2005). These factors result in plants with physiological and a few times morphologic alterations, which hinder their survival when transferred to ex vitro conditions (Dhiraj et al. 2003, Hazarika 2003, Martin and Pradeep 2003). Attainment of photosynthetic properties during the hardening phase constitutes a decisive phase when adapting to natural conditions (Arditti and Krikorian 1996, Sharma et al. 1999, Dhiraj et al. 2003, Nagaraju and Mani 2005). Accordingly, the selection of substrates that will ensure survival of plants taken from in vitro conditions is a key issue that must be addressed. Not many published works have dealt with this subject. Studies by González et al. (1994) and Arciniegas (1996) concentrated on investigating efficient substrates to be used in the hardening of the genus Cattleya, finally recommending fragments of fern rhizome (Cyathea sp.). The present work evaluated the performance of alternative substrates that would not require the disturbance of any threatened species. They should also be inexpensive and easy to obtain during the hardening stage of $C$. trianae.

\section{MATERIALS AND METHODS}

\section{Source and preparation of plant materi-} al: $C$. trianae seedlings were obtained from the orchid bank of the Tissue Culture Laboratory, Universidad del Tolima. They were grown from seed and maintained in Knudson C medium (Knudson 1946). Plants were selected according to their morphological characteristics (color, vigor, size, and presence of a root system). They were then put through an in vitro invigoration process for six months, cultured in NEO medium (Mesa, unpub. data), proposed and tested in the Tissue Culture Laboratory, Universidad del Tolima (Table 1). Plants were extracted from the flasks, washed in water, submerged in Dithane M-45 (Mancozeb, a practically non-toxic ethylene bisdithiocarbamate) fungicide $(1.56 \mathrm{~g}$ per $0.5 \mathrm{l})$ for sanitary control, and randomly placed in each treatment.

Substrates evaluated during hardening stage: substrates were selected considering relative resistance to decomposition, good water retention, and sufficient airflow. The following substrates were tested: pine bark (Pinus patula), coconut fiber (Cocos nucifera), vegetable coal, icopor (polystyrene foam) and wood shavings (Table 2). Ten treatments were evaluated into a growth room displayed relative humidity $(98 \%)$. The percentage of fungal infection also was recorded.

Substrate preparation and transplanting: for the acclimation stage the substrates were sterilized in a $2.5 \%$ sodium hypochlorite $(\mathrm{NaOCl})$ solution. They were then sterilized in an autoclave and dried in a stove at $180^{\circ} \mathrm{C}$ for 3 h. After cooling they were put in sterile plastic trays, which measured $55 \mathrm{~cm}$ x $28 \mathrm{~cm}$, contain 25 cells $5 \mathrm{~cm}$ deep, and have a surface area of $30 \mathrm{~cm}^{2}$. Plants were transplanted and trays labelled. Once every eight days during the first 32 days, we applied $5 \mathrm{ml}$ doses of Murashige \& Skoog salts (M\&S, Murashige and Skoog 1962) at half concentration. Trays were covered with plastic lids during the first 30 days. Plants were watered daily using a sprinkling system with sterile distilled water. After a month, plants were watered with tap water. Fungal control consisted of the application of benomyl: methyl-1-(butylcarbamoyl)-2-benzimidazole carbamate (as the pure compound of the commercial preparation Benlate WP-systemic fungicide to 0.36 g per 0.51 ) every two days or as necessary depending on the phytosanitary evaluation. 
TABLE 1

Formulation of culture media and nutritional supplements for the hardening of $\mathrm{C}$. trianae

Salts

Chemical Formula

Formulation (mg/l)

Macronutrients

Ammonium nitrate

Potassium nitrate

Calcium chloride

Calcium nitrate

Ammonium sulphate

Potassium phosphate

Ammonium acid phosphate

Micronutrients

Boric acid

Sodium molybdate

Cobalt chloride

Potassium iodide

Magnesium sulfate

Manganese sulfate

Zinc sulfate

Copper sulfate

Sodium salt of ethylene diamine tetraacetic

Ferrous sulphate

Nutritional supplements

Thiamine

Nicotinic acid

Glycine

Pyridoxine

Hydrolyzed casein

Myoinositol

Sucrose

Other components

Activated carbon

Banana

Pineapple
M\&S

(1962)

$\mathrm{NH}_{4} \mathrm{NO}_{3} \quad 1650$

1900

$\mathrm{Neo}$
$(1999)^{*}$

Knudson C

(1946)

$\mathrm{KNO}_{3}$

$\mathrm{CaCl}_{2} \cdot 2 \mathrm{H}_{2} \mathrm{O}$

440

700

850

100

$\mathrm{Ca}\left(\mathrm{NO}_{3}\right)_{2} .4 \mathrm{H}_{2} \mathrm{O}$

$\left(\mathrm{NH}_{4}\right)_{2} \mathrm{SO}_{4}$

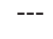

100

$\mathrm{KH}_{2} \mathrm{PO}_{4}$

$\mathrm{NH}_{4} \mathrm{H}_{2} \mathrm{PO}_{4}$

$\mathrm{H}_{3} \mathrm{BO}_{3}$

$\mathrm{Na}_{2} \mathrm{MoO}_{4} \cdot 2 \mathrm{H}_{2} \mathrm{O}$

6.2

0.25

$\mathrm{CoCl}_{2} \cdot 6 \mathrm{H}_{2} \mathrm{O}$

0.025

0.83

370.0

22.3

8.6

0.025

37.3

27.8

2.5

$\mathrm{FeSO}_{4} \cdot 7 \mathrm{H}_{2} \mathrm{O}$

0.1

0.5

2.0

0.5

100

100

30000

20000

20000

$\begin{array}{lll}--- & 3000 & 100\end{array}$

-- $\quad$--- $100 \mathrm{ml}$

--- --- $\quad 100 \mathrm{ml}$

* Mesa, N. 1999. Proyecto de investigación en el Laboratorio de Cultivo de Tejidos, Universidad del Tolima. Unpublished data. 
TABLE 2

Treatments evaluated during hardening stage of $\mathrm{C}$. trianae

$\begin{array}{clc}\text { Treatments } & \text { Substrates } & \text { Proportions } \\ \text { T1 } & \text { Pine bark } & 1 \\ \text { T2 } & \text { Coconut fiber } & 1 \\ \text { T3 } & \text { Pine -Coconut } & 1: 1 \\ \text { T4 } & \text { Pine -Coconut-Coal } & 1: 1: 1 \\ \text { T5 } & \text { Pine-Coconut-Icopor } & 1: 1: 1 \\ \text { T6 } & \text { Pine-Shavings-Coal } & 1: 1: 1 \\ \text { T7 } & \text { Pine-Shavings-Icopor } & 1: 1: 1 \\ \text { T8 } & \text { Coconut-Shavings-Coal } & 1: 1: 1 \\ \text { T9 } & \text { Coconut-Shavings-Icopor } & 1: 1: 1 \\ \text { T10 } & \text { Coal-Icopor-Shavings } & 1: 1: 1\end{array}$

Record of morphometric variables: we used the following growth indicators: length of longest leaf $(\mathrm{cm})$, biomass (wet weight, $\mathrm{g}$ ), and number of leaves and roots. Number of leaves and leaf length variables were measured every 15 days. The other variables were recorded at the beginning and at the end of the tests. Percent survival was recorded at the end of the experiment. Data were also collected or environmental factors, such as relative humidity $(\%)$, temperature $\left({ }^{\circ} \mathrm{C}\right)$, and percentage with fungal infection.

Greenhouse phase: surviving plants after of the hardening were individually transplanted to substrates of only coconut fiber or coconut fiber mixed with pine and coal (treatments two, three and four respectively). Half of the resulting plants were taken to the greenhouse and placed in the shade, temperature of $25 \pm 2{ }^{\circ} \mathrm{C}$, relative humidity of $80 \%$, and were continually misted with water. The other half of the plants were kept under full light, a temperature of $27.4{ }^{\circ} \mathrm{C}$, relative humidity of $58 \%$, and were watered twice a day.

Statistical analysis: each treatment was made up of 25 plants. However, at the end of the experiment, plant survival was different for each treatment, so uneven sample sizes were used for statistical analysis. To fulfil the assumptions of homoscedasticity and normality, data (leaf length and biomass) were $\log$ transformed $\left(y=\log _{10}+1\right)$ (Zar 1999). A one-way MANOVA was used to evaluate the effect of treatments on dependent variables (leaf length and biomass). Duncan's a posteriori test was done to compare significant treatments. In order to analyze the effect of treatments on the dependent variable for survival, and one way ANOVA (fixed factor) and Duncan's a posteriori test were carried out. Statistical analysis was done using STATISTICA version 7.0 (StatSoft 2004).

\section{RESULTS}

Phytosanitary control: the highest percentages of fungal infestation occurred on treatments of pine bark (T1) $(75 \pm \mathrm{SE}=0.24)$ and on pine-coconut (T3) $(74 \pm \mathrm{SE}=0.37)$. The remaining tested substrates presented fungal contamination equal to or below $(22 \pm \mathrm{SE}=0.34)$. Lowest percentages were recorded for treatments containing inert substrates, reaching $0 \%$ in the case of coal-polystyrene-shavings (T10) (Fig. 1B).

Acclimatization and hardening: during the acclimation the growth was slow, but the physical appearance of the plants indicated tolerance. The 16 weeks long hardening period was critical for $53 \%$ of the tested population. Highest mortality rates were observed during the hardening for plants growing on pine bark (T1).

Percentage survival: there were significant differences in survival of $C$. trianae on different substrates $\left(\mathrm{F}_{9,40}=4.631, \mathrm{p}<0.001\right)$. Results from Duncan's test are shown in Table 3. Substrates of pine-coconut (T3), coconut fiber (T2) and pine-coconut-coal (T4) had the highest percent survival $(80,76$, and $60 \%$, respectively), while the lowest percent survival was recorded for pine bark (T1) at $12 \%$ (Fig. 1A). 

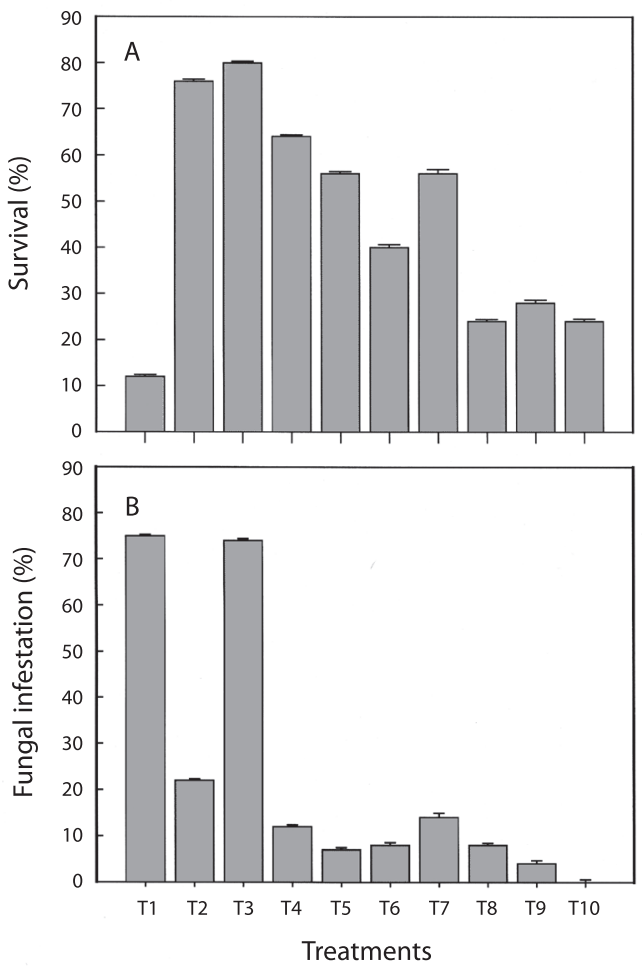

Fig. 1. (A) Survival percentage in plants ( $\pm 1 \mathrm{SE})$; (B) percentage of fungal infestation of substrates during the hardening phase of $C$. trianae $( \pm 1 \mathrm{SE})$.

\section{Growth indicators}

Leaf length and biomass (fresh weight): coconut fiber (T2), pine-coconut (T3) and pine-coconut-coal (T4) stimulated leaf growth most effectively. Plants growing on pine bark (T1) had the poorest growth rates (Fig. 2A). Qualitative observations, such as number and dimensions of leaves and roots, point towards coconut fibre (T2), as the substrate that allowed the greatest increase for the biomass (fresh weight) variable. On the other hand, pine bark (T1) proved to be a hindrance to increase in biomass (Fig. 2B).

The treatments (T2-T9) showed marked differences regarding morphological variables such as leaf length and biomass (MANOVA, Wilk's Lambda $=0.765156$, d.f. $=16, \mathrm{p}=0.026$ ). Pine bark (T1) was omitted from analysis due to the elevated index of plant mortality
TABLE 3

Duncan's test in the survival of $\mathrm{C}$. trianae showing comparative averages of substrates

$\begin{array}{clcc}N^{\circ} & \text { Treatment } & \text { Mean } & \mathrm{p}<0.05^{*} \\ 1 & \text { Pine bark } & 1.6 & \mathrm{e} \\ 2 & \text { Coconut fiber } & 5 & \mathrm{ab} \\ 3 & \text { Pine-Coconut } & 5.2 & \mathrm{a} \\ 4 & \text { Pine-Coconut-Coal } & 4.2 & \mathrm{abc} \\ 5 & \text { Pine-Coconut-Icopor } & 3.8 & \mathrm{abcd} \\ 6 & \text { Pine-Shavings-Coal } & 3 & \mathrm{cde} \\ 7 & \text { Pine-Shavings-Icopor } & 3.8 & \mathrm{~cd} \\ 8 & \text { Coconut-Shavings-Coal } & 2.2 & \mathrm{de} \\ 9 & \text { Coconut-Shavings-Icopor } & 2.4 & \mathrm{cde} \\ 10 & \text { Coal-Icopor-Shavings } & 2.2 & \mathrm{de}\end{array}$

*a, b, c, d, e: means with same letters do not vary significantly $(\mathrm{p}<0.05)$.
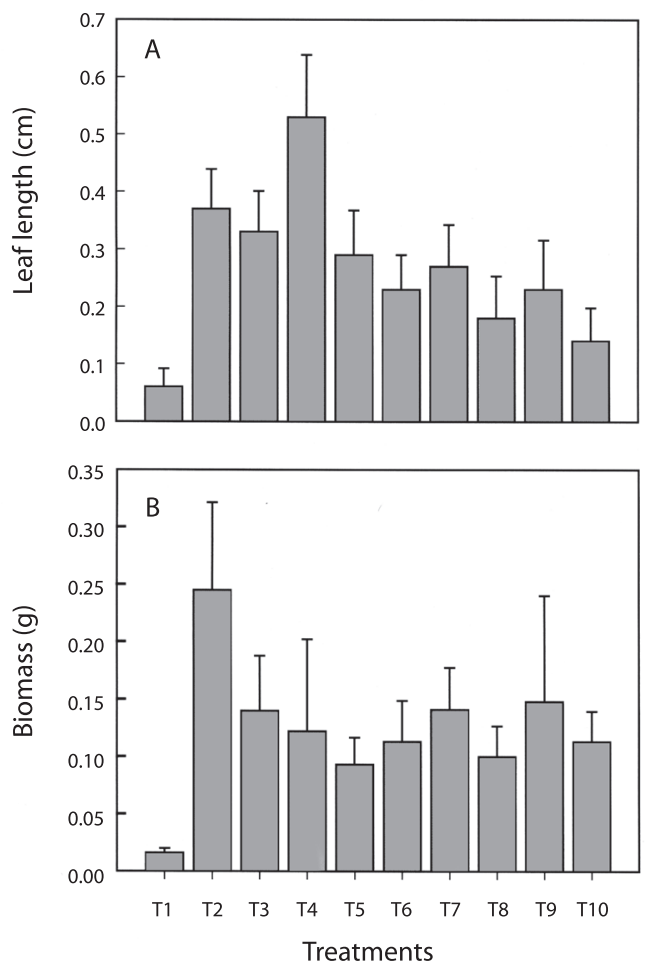

Fig. 2. (A) Leaf length increase of $C$. trianae ( $\pm 1 \mathrm{SE})$; (B) Biomass increase during the hardening phase $( \pm 1 \mathrm{SE})$. 
when using this treatment. The leaf length variable showed differences for the between treatments T2-T3 (Duncan's test, $\mathrm{p}=0.0399$ ), T3-T4 $(\mathrm{p}=0.0395), \mathrm{T} 3-\mathrm{T} 9 \quad(\mathrm{p}=0.0343), \mathrm{T} 8$ T9 $(\mathrm{p}=0.0447)$ and for the biomass variable between T7-T8 $(\mathrm{p}=0.0482)$.

Numbers of leaves and roots: due to the behaviour of these variables during the study (the tendency of plants to lose leaves and roots), statistical differences between treatments could not be established.

\section{DISCUSSION}

Phytosanitary control: contamination by fungi and bacteria from the air, water, tools, glassware, and other sources may occur in orchid seedling and tissue cultures. Surface sterilization of the seeds or tissues can prevent initial contamination, but microorganisms often find their way into cultures at a later date. Incorporation of benomyl and another fungicides and bactericides in several combinations, can prevent or inhibit contamination of $C$. aurantiaca and Stanhopea occulata seedlings in vitro and Phalaenopsis flower stalk node cultures without adversely affecting the plants (Brown et al. 1982). Bayman et al. (2002) demonstrated that benomyl-treated plants of the orchid Lephantes rupestris had significantly lower mortality than controls (treated with water), and significantly fewer fungi in leaves that control plants. Sterilized substrates, control of environmental variables, and the source of the seedlings probably inhibited bacterial contamination in all treatments. Pine bark alone, or mixed with coconut fiber, increased fungal proliferation, so it is necessary to treat these substrates with more efficient disinfection techniques. Mendizabal (2001) recommends a controlled decomposition process for pine bark in order to inhibit pathogenic fungal activity. According to Cañas (1994), inert substrates are virtually unaffected by fungal and bacterial contamination. This was confirmed in this study for icopor (polystyrene foam) and coal.
González et al. (1994), argued that the application of different fungicides in adequate doses does not seem to inhibit the growth of Cattleya dowiana, a point confirmed by the positive results obtained in this study when using the systemic fungicide benomyl (Benlate) in doses of $0.36 \mathrm{~g}$ per $500 \mathrm{ml}$. Also, there was no evidence of plant death due to fungal action. Thurston et al. (1979) recorded that some fungicides and bactericides can kill the seedlings, to induce deformed growth, or generally inhibiting development of $C$. aurantiaca and $S$. occulata. Others as Benlate had no observable effects, and enhanced growth, improving root and shoot development.

Acclimation and hardening: acclimation is an important step in micropropagation. During in vitro growth, plants develop under controlled conditions, including enclosed environments, without gaseous exchanges, with high moisture in the air, low light intensity, and the use of sugars from the medium as a source of carbon and energy (Pospísilová et al. 1999). Thus, the transplanting of in vitro-grown plantlets and the complete establishment in the greenhouse can be complex for some species (Hazarika 2003). The selection of a suitable substrate can be decisive for acclimation (Viegas et al. 2005). Preece and Sutter (1991), Ziv (1991), Teixeira et al. (1995), Inoue et al. (1999), affirm that keeping plants in vitro produces physiological, structural, and anatomical abnormalities; such as absence of waxy cuticle, non functional stomates, photosynthetic inefficiency, and malfunctioning of hydric transport, these abnormalities resulting in elevated evapotranspiration rates.

Driver and Suttle (1987), Ziv (1991), Donelly and Tisdall (1993), Agramante et al. (1998), indicated that it is necessary to maintain high relative humidity and low light intensity until plants have adequately developed stomates and cuticle. They also recommend a gradual conditioning to lower humidity and light intensity in order to avoid photoinhibition of the photosynthetic apparatus. This study found that keeping plants of $C$. trianae, 
which thrive only under shady conditions, and under constant atmospheric conditions (relative humidity $=98 \%$ and shadow) for the first two weeks of acclimation, improved survival during this phase (Franco, pers. obs.). According to Hazarika (2003), controlling nitrogen levels during the hardening phase is critical to enhancing plant growth. Therefore, the addition of M\&S salts allowed plants to gradually adapt to autotrophic conditions.

High mortality rates among plants growing on pine bark was possibly due to low humidity retention in this substrate, preventing proper root development and strong anchorage of the root system. The acclimation and hardening phase was a key stage in the assessment of substrate efficiency. According to our observations, the best acclimation strategy was to condition plants for 30 days, then leaves them exposed outdoors in places where conditions are similar to those required by the plant in its natural habitat.

Survival or adaptation percentages: the greenhouse and field have substantially lower relative humidity, higher light level and septic environment that are stressful to micropropagated plants compared to in vitro conditions. The benefit of any micropropagation system can, however, only be fully realized by the successful transfer of plantlets from tissue-culture vessels to the ambient conditions found ex vitro (Hazarika 2003). Percent survival was measured considering those plants that lasted from the beginning of the acclimation stage until the end of the greenhouse phase. No bibliographic references were found to compare with the results obtained in this study regarding percent survival of $C$. trianae during its conditioning from in vitro to in vivo. However, Saiprasad and Polisetty (2003) showed that the orchids Dendrobium, Oncidium and Cattleya had complete survival or establishment in potting media having wood charcoal pieces alone and wood charcoal + brick pieces, they attributed these results to the presence of wood charcoal and/or brick pieces, which allowed good circulation of air and excellent drainage. Minimum survival $(<60 \%)$ was observed when soilrite alone was used as the potting medium, possibly because soilrite retains high moisture, but aeration may be inadequate.

Survival fluctuation among different treatments could be explained through the variation in chemical composition and physical properties of the substrates employed (porosity and water retention capacity). Coconut (T2) and pine-coconut (T3) showed significantly higher percent survival. This could be due to the fibrous texture, good hydric retention, anchorage capacity, and porosity of coconut fibre. Lowest survival percentages were obtained with pure pine treatment, due to low water retention capacity, non-fibrous texture, and the low density of dry pine bark, hindering anchorage of the roots. This result differs from reported by Mendizabal (2001), who considers crushed pine bark to be one of the best organic substrates for the propagation of epiphytic orchids, serving as a superior alternative to artificial substrates. The data from the present study do not corroborate the interpretation given by Mendizabal (2001). Our results suggest that pine is not a favourable substrate in the hardening process of $C$. trianae. Better results were obtained when it was mixed with substrates that improve anchorage. Substrates with higher water retention properties (without it being excessive), showed improved survival rates of Cattleya.

Leaf length: treatments with coconut fibre alone or in a mix, stimulated leaf growth better than others. Growth was fair limited in substrates containing pine, and low in the rest. These results differed from those found by Arciniegas (1996), who maintains that the Cyathea substrate promotes better leaf growth in $C$. trianae than in the coconut fiber. It is important to refer that grown of the orchids is often quite slow during their life cycle. It is even more important for Cattleya, which takes years to develop into a mature plant (Ortiz 1995, Villee 1996). This slow rate of growth was corroborated during the present study. 
Biomass: treatments T7 (pine-shavingsicopor) and T8 (coconut-shavings-coal) were the substrates that showed the lowest performances, according to the statistical analyses, compared with the rest of treatments. Poor anchorage ratios and poor water retention capacities meant that orchids had low survival rates during the hardening stage. This could change if they were used in combination with organic substrates that contribute better aeration, anchorage, and water retention. On the other hand, plants grown using coconut and coconut-shavings-icopor treatments had vigorous, healthy appearances good, velamen growth, strong adherence of roots to the substrate, rigid and coriaceous leaf structures (possibly due to the production of lignins, cutines, and wax on the surface of the cuticle) (Azcon and Talon 1993). A very conspicuous feature of the Orchidaceae is a root equipped with a multilayered epidermis covering the aerial and terrestrial roots of orchids, the velamen, which is underlaid by a distinct cortical exodermis (Engard 1944). Aspects of the structure and function of a variety of orchid roots have been described in some detail, yet controversy continues over how these organs operate to procure minerals and moisture, avoid desiccation and provides mechanical protection of the roots (Dycus and Knudson 1957, Benzing et al. 1982, Pridgeon et al. 1983). The velamen appeared around the $8^{\text {th }}$ week in treatments containing coconut fiber, demonstrating that plants are developing morphological responses homologous to those observed in the field (Pridgeon et al. 1983).

Leaves and roots: no statistical significant differences were recorded for these variables among tested treatments, because at the beginning of the experiment plants suffered leaf and root loss. At the beginning of the acclimation stage, plants started triggering physiological processes in response to environmental changes occurring when they were transferred from in vitro to in vivo, which stimulates the senescence and abscission of damaged organs
(Pospísilová et al. 1999, Azcon and Talon 2001, Hazarika 2003, Viegas et al. 2005).

The process of abscission observed in the experimental units is possibly due to the plants decreasing respiratory demands and reducing the exposed area of unnecessary structures, which decrease the effects produced by different kinds of stress. Advanced symptoms of chlorosis, followed by death of the leaves, were observed in some experimental units. It is possible that a similar situation might have occurred with root loss (Azcon and Talon 1993), although this particular point was not confirmed. Root loss affected only some of the sampled treatments. Since data for this variable was recorded twice, at the beginning and at the end of the experiment, it is difficult to establish what factors might have influenced the loss of these organs at some stage of the hardening process. Therefore, it is not possible to make assumptions about the effects of substrates on these two variables.

Greenhouse phase: plants kept in shady conditions, $\mathrm{RH}=80 \%, \mathrm{~T}=25.3{ }^{\circ} \mathrm{C}$ and under continual misting, looked very healthy the third day onward, so it would seem advisable to apply these findings in other studies. Plants grown without shading suffered morphological changes provoked by excessive absorption of light. These changes could possibly be due to an increase in wax or salt deposits on the upper surface of the leaves resulting in reflective surfaces, or to other mechanisms, such as the redistribution of chloroplasts in the mesophyll cells, leaf curling, and wilting (Azcon and Talon 1993, Hazarika 2003).

This study recommends a protocol for the management of $C$. trianae during the hardening phase. Also, it is advisable to use efficient, economically viable substrates (coconut, pinecoconut, and pine-coconut-coal) as alternatives to the tree fern Cyathea sp., in order to ensure a lessened impact on this threatened species. The resulting plants remain attached to trees in the wild, fulfilling the objective of reintroducing this species in natural ecosystems. 


\section{Standard protocol}

1. Prepare and sterilise substrate components (coconut fiber or coconut fiber-coal-pine bark).

2. Place wet and sterilized substrate in germination tray cells.

3. From vitroplants kept in NEO medium for fourth months, select specimens with developed root systems.

4. Wash agar residues stuck to the roots.

5. Disinfect plants using Dithane M-45 (1.56 g per 0.51 ).

6. Transplant a vitroplant in each cell of the germination tray, burying part of the roots in the substrate and leaving the rest exposed. Provide water and place in the shade.

7. Cover each tray with a plastic lid, preventing these from touching the leaves.

8. Apply daily misting with distilled sterilized water, and water every eight days with half concentration M\&S solution for a month. Apply Benlate $(0.36$ g per 0.5 l) in case of fungal infestation.

9. After three weeks, remove plastic lid for 4 $\mathrm{h}$ a day during eight days; then remove the cover for good.

10. Transfer trays to a shady place for eight days and later to a site with $50 \%$ direct sunlight.

11. From weeks 6 to 18 provide, irrigate plants with tap water using an atomizer or sprayer.

12. Transplant each whole block of substrate to individual containers, filling them up with coconut fiber or a mixture of organic substrates plus icopor (polystyrene foam) and/or coal, to promote aeration and drainage.

13. Transfer plants to a shady, well-ventilated place, where relative humidity borders on $80 \%$. Install a sprinkling system or provide water every $12 \mathrm{~h}$, and avoid water logging or excessive humidity.

14. Transplant to environments similar to those where C. trianae grows naturally.
In conclusion, a simple and efficient protocol for mass propagation of C. trianae from plantlets has been established. Using this protocol, it is possible to produce viable, uniform and healthy plants with the maximum survival rate that can be used for large scale cultivation, which is important from economical point view from this species. Furthermore, the protocol may facilitate conservation of this ornamental orchid from extinction in the natural population. Currently, many tropical orchid species have been propagated through a range of asymbiotic seed germination techniques and tissue culture procedures aimed to preserve a number of individuals under artificial conditions in glasshouses, with the aim to protect these species from complete extinction.

\section{ACKNOWLEDGMENTS}

We thank Carlos Lehnebac and Maria Teresa Gonzales for comments and suggestions that greatly improved the manuscript. The first author was supported by the $\mathrm{PhD}$ fellowship from the Comisión Nacional de Investigación Científica y Tecnológica (CONICYT) during the preparation of manuscript.

\section{RESUMEN}

Cattleya trianae es una especie endémica de los bosques tropicales de los Andes colombianos. Actualmente se encuentra amenazada por la disminución de su hábitat natural y la sobreexplotación con fines comerciales. En este estudio se evaluó el efecto de diez tratamientos con sustratos biológicos (corteza de pino, fibra de coco y viruta) e inertes (esferitas de "icopor" y carbón vegetal) en diferentes combinaciones, sobre aspectos morfométricos y fenotípicos en la etapa de endurecimiento de 250 vitroplantas de C. trianae. Se registró porcentaje de supervivencia, longitud de la hoja, biomasa en peso fresco, número de raíces y hojas al inicio y al final del experimento. Al finalizar la fase de endurecimiento, las vitroplantas fueron llevadas a invernadero y posteriormente a ambiente natural. La fibra de coco sola ó mezclada en partes iguales con pino y carbón vegetal, fue el sustrato más eficiente cuando se evaluó el porcentaje de supervivencia $(80 \% \pm \mathrm{SE}=0.3742)$, biomasa en peso fresco y longitud de hoja. Las plantas 
endurecidas mostraron características cualitativas como vigorosidad, textura coriácea y cerosa, verdor intenso en sus hojas y velamen. En condiciones de invernadero las plantas se desarrollan mejor con luz filtrada, humedad relativa alrededor del $80 \%$, aireación continua, nebulización y temperatura promedio de $25 \pm 2{ }^{\circ} \mathrm{C}$. Las plantas vigorizadas mostraron buen anclaje y adaptación en árboles.

Palabras clave: aclimatación, endurecimiento, sustratos, ornamentales, orquídeas, conservación, Cattleya trianae.

\section{REFERENCES}

Agramonte, D., F. Jiménez \& M. Dita. 1998. Aclimatización, p. 12-24. In J.N. Pérez (ed.). Propagación y Mejora Genética de Plantas por Biotecnología. Instituto de Biotecnología de las Plantas, Santa Clara, Cuba.

Arciniegas, N.R. 1996. Evaluación de sustratos para el endurecimiento de Catleya trianae Lind \& R.chb.f. Tesis de Pregrado, Universidad del Tolima, Ibagué, Colombia. 128 p.

Arditti, J. \& A.D. Krikorian. 1996. Orchid micropropagation: the path from laboratory to commercialization and an account of several unappreciated investigators. Bot. J. Linn. Soc. 122: 183-241.

Azcón, J. \& M. Talón. 1993. Fisiología y Bioquímica Vegetal. McGraw Hill Interamericana, Madrid, España. 485 p.

Azcón, J. \& M. Talón. 2001. Fundamentos de fisiología vegetal. Universidad de Barcelona, McGraw Hill Interamericana, Madrid, España. 522 p.

Bayman, P., E.J. González, J.J. Fumero \& R.L. Tremblay. 2002. Are fungi necessary? How fungicides affect growth and survival of the orchid Lepanthes rupestris in the field. J. Ecol. 90: 1002-1008.

Benzing, D.H., D.W. Ott \& W.E. Friedman. 1982. Roots of Sobralia Macrantha (Orchidaceae) structure and function of the velamen-exodermis complex. Amer. J. Bot. 69: 608-614.

Brown, D.M., C.L. Groom, M. Cvitanik, M. Brown, J.L. Cooper \& J. Arditti. 1982. Effects of fungicides and bactericides on orchid seed germination and shoot tip cultures in vitro. Plant Cell Tiss. Org. 1: 165-180.

Cañas, C.B. 1990. Informe final Cultivo in vitro de Orquídeas. Universidad Industrial de Santander, Facultad de Ciencias. Departamento de Biología, Bucaramanga, Colombia. 20 p.
Constantino, E. \& E. Calderón. 2002. Informe final Convenio de Cooperación Científica y Tecnológica. No. 29. MMA- IAvH. Proyecto Cattleya $1^{\mathrm{a}}$ fase, Bogotá, Colombia.

Dhiraj, N., V. Varsha \& B. Sujeta. 2003. Provenance and subculture-dependent variation during micropropagation of Gmelina arborea. Plant Cell Tiss. Org. 73: 189-195.

Díaz, S. 1987. Algunas consideraciones sobre la palma de cera del Quindío y sobre la flor de mayo como símbolos nacionales. Rev. Acad. Colom. Cienc. Exac. Fís. Nat. 16: 145-152.

Donnelly, D. \& L. Tisdall. 1993. Acclimatization strategies for micropropagated plants, p. 153-166. In M.R. Ahuja (ed.). Micropropagation of woody plants (Forest science v.41). Kluwer Academic, Dordrecht, Netherlands.

Driver, J.A. \& G.R. Suttle. 1987. Nursery handling of propagules, p. 320-335. In J.M. Bonga \& D.J. Durzan (eds.). Cell and tissue culture in forestry. Specific principles and methods: growth and developments. Martinus Nijhoff, Dordrecht, Netherlands.

Dycus, A.M. \& L. Knudson. 1957. The role of the velamen of the aerial roots of orchids. Bot. Gaz. 119: 78-87.

Engard, C.J. 1944. Morphological identity of the velamen and exodermis in orchids. Bot. Gaz. 105: 457-462.

González, L., M.I. González, D.E. Mora de Retana \& J. Warner. 1994. Crecimiento de Cattleya dowiana (Orchidaceae) en varias condiciones de cultivo. Rev. Biol. Trop. 42: 73-79.

Hazarika, B.N. 2003. Acclimatization of tissue-cultured plants. Curr. Sci. India 85: 1704-1712.

Inoue, M.T., J.D. Vieira \& G. Correa. 1999. Estudio comparativo del desempeño fotosintético entre posturas micropropagadas y de estacas de cuatro clones del híbrido Eucalyptus grandis x E. urophylla. Congreso Forestal Brasilero, 6. Campos de Jordao, Anais, Brazil. 496 p.

Knudson, L. 1946. A new nutrient solution for germination of orchid seed. Amer. Orch. Soc. Bull. 15: 214-217.

Krapiec, P.V., M.A. Milaneze \& M.F.P. Silva. 2003. Effects of different combinations of growth regulators for bud induction from seedlings of Cattleya walkeriana Gardner (Orchidaceae). Acta Scientiarum 25: 179-182. 
Martin, K.P. \& A.K. Pradeep. 2003. Simple strategy for the in vitro conservation of Ipsea malabarica an endemic and endangered orchid of the Western Ghats of Kerala, India. Plant Cell Tiss. Org. 74: 197-200.

Murashige, T. \& F. Skoog. 1967. A revised medium for rapid growth and bioassays with tobacco tissue cultures. Physiol. Plant. 15: 473-497.

Murashige, T. 1974. Plant propagation through tissue cultures. Ann. Rev. Plant. Physiol. 25: 135-66.

Murillo, A.J. \& M.T. Murillo. 2003. Pteridófitos de Colombia IV. Novedades en Cyathea (Cyatheaceae). Rev. Acad. Colom. Cienc. Exac. Fís. Nat. 27: 45-51.

Nagaraju, V. \& S.K. Mani. 2005. Rapid in vitro propagation of orchid Zygopetalum intermedium. J. Plant Biochem. Biot. 14: 27-32.

Ospina, H.M. 1974. Anales de la Séptima Conferencia Mundial de Orquideología. Bedout, Medellín, Colombia. 357 p.

Ospina, H.M. \& R.L. Dressler. 1979. Orquídeas de las Américas. Arco, Bogotá, Colombia. 496 p.

Ortiz, V.P. 1976. Orquídeas de Colombia (Géneros) Universidad Javeriana, Bogotá, Colombia. 115 p.

Ortiz, V.P. 1995. Orquídeas de Colombia. Corporación Capitalina de Orquideología. Bogotá, Colombia. 320 p.

Pospísilová, J., I. Tichá, P. Kadlecek, D. Haisel \& S. Plzáková. 1999. Acclimatization of micropropagated plants to ex vitro conditions. Biol. Plantarum 42: 481-497.

Preece, J.E \& E.G. Sutter. 1991. Acclimatization of micropropagated plant to the greenhouse and field, p. 71-93. In P.C. Debergh \& R.H. Zimmerman (eds.). Micropropagation Technology and Application. Kluwer Academic, Dordrecht, Holland.

Pridgeon, A.M., W.L. Stern \& D.H. Benzing. 1983. Tilosomes in Roots of Orchidaceae: Morphology and Systematic Occurrence. Amer. J. Bot. 70: 1365-1377.
Saiprasad, G.V.S. \& R. Polisetty. 2003. Propagation of three orchid genera using encapsulated protocormlike bodies. In Vitro Cell. Dev. Biol. Plant 39: 42-48.

Sharma, M., A. Sood, P. Nagar, O. Prakash \& P. Ahuja. 1999. Direct rooting and hardening of tea microshoots in the field. Plant Cell Tiss. Org. 58: 111-118.

Teixeira, J.B., J.I. Lemos \& M.C. Coelhe. 1995. Micropropagaçâo de espécies leñosas da mata atlántica. Anais Congreso Brasileiro de Fisiología Vegetal, Lavras, Brazil.

Thurston, K.C., S.J. Spencer \& J. Arditti. 1979. Phytoxicity of fungicides and bactericides in orchid culture media. Amer. J. Bot. 66: 825-835.

Viegas, P.H., A.M.L. Pereira, G.M.B. Ambrosano \& M.de F. Batista. 2005. Acclimatization of micropropagated Heliconia bihai (Heliconiaceae) plants. Sci. Agric. (Piracicaba, Braz.) 62: 299-301.

Villee, C.A. 1996. Biología. McGraw Hill Interamericana, México DF, México. 946 p.

Zar, J.H. 1999. Biostatistical Analysis. Prentice Hall, New Jersey, USA. 662 p.

Ziv, M. 1991. Vitrification: morphological and physiological disorders of "in vitro" plant, p. 49-69. In P.C. Debergh \& R.H.Zimmerman(eds.). Micropropagation Technology and Application. Kluwer Academic, Dordrecht, Holland.

\section{INTERNET REFERENCES}

CITES. 2003. Decimotercera reunión del Comité de Flora. Ginebra, Suiza. (http://www.cites.org/esp/append/ index.shtml. Downloaded: August 4, 2004).

Mendizabal, M.O. 2001. Preparación de medios de crecimiento artificial utilizando desechos orgánicos. Instituto Politécnico Nacional: centro de estudios científicos y tecnológicos. (http://members.tripod. com/ urbieta_3/cultivo.htm. Downloaded: July 15, 2002). 
